\title{
Dynamics Analysis of Surface Temperature and Vegetation Index in Settlement Area around the Lokon Volcano, Tomohon, North Sulawesi
}

\author{
Djeli Alvi Tulandi, Armando Ariakta Aloanis \\ Department of Physics, Universitas Negeri Manado, Tondano, Indonesia \\ Email: djelitulandi@unima.ac.id
}

How to cite this paper: Tulandi, D., \& Aloanis, A. A. (2021). Dynamics Analysis of Surface Temperature and Vegetation Index in Settlement Area around the Lokon Volcano, Tomohon, North Sulawesi. Journal of Geoscience and Environment Protection, 9, 118-129.

https://doi.org/10.4236/gep.2021.910009

Received: August 29, 2021

Accepted: October 24, 2021

Published: October 27, 2021

Copyright $\odot 2021$ by author(s) and Scientific Research Publishing Inc. This work is licensed under the Creative Commons Attribution International License (CC BY 4.0).

http://creativecommons.org/licenses/by/4.0/

(c) (i) Open Access

\begin{abstract}
Mount Lokon is an active mountain near residential areas such as cities Tomohon, Tondano, and Manado. Along with the increasing population and population development around Mount Lokon, vegetation is decreasing due to converting land from grassland to land use for human activities. Using Landsat 8 OLI/TIRS images, this study was conducted to analyze the surface temperature and vegetation index dynamics around Mount Lokon, including the residential areas. Found that an increase in mean temperature occurred, and the peak increased dramatically in 2018 with temperatures $>26^{\circ} \mathrm{C}$. This result, of course, correlates with the decreasing vegetation area. However, the decline occurred in 2020 due to decreased human activities and land clearing for new settlements caused by activity restrictions which were the effects of the COVID-19 pandemic. Reforestation efforts must be made to increase the vegetation around Mount Lokon, including residential areas. The average surface temperature can be controlled, and living creatures can be given comfort to living things around them even after the pandemic and human activities return to normal.
\end{abstract}

\section{Keywords}

Remote Sensing Technology, Land Surface Temperature, NDVI, Dynamics

\section{Introduction}

Mount Lokon is one of the volcanoes that frequently erupts located in Tomohon, North Sulawesi Province. Often called the Lokon-Empung Complex, the morphology shows that the peak of Mount Lokon is adjacent to Mount Empung, $2.3 \mathrm{~km}$ apart, and can be categorized as twin mountains (Riyadhi et al., 2017). 
Located at $01^{\circ} 21.5^{\prime}$ north longitude and $124^{\circ} 47^{\prime}$ east longitude, the peak of Mount Lokon has an altitude of 1579.5 meters above sea level. In contrast, at $01^{\circ} 22^{\prime} \mathrm{LU}$ north longitude and $124^{\circ} 47^{\prime}$ east longitude is Mount Empung with an altitude of $1340 \mathrm{~m}$ above sea level and has a crater named Tompaluan is located at an altitude of 1140 masl (Pusat Vulkanologi dan Mitigasi Bencana Geologi, 2014).

The location of the Lokon volcano is close to the cities of Tomohon, Tondano, and Manado. The increase in population certainly affects the expansion of settlements and vegetation area and, of course, changes in surface temperature in settlements around Mount Lokon.

The world's attention has recently become increasingly focused on anthropogenic influences on the environment. Urbanization which is correlated with an increase in population is the reason for changes in land use. Urban development significantly impacts the earth's surface, where natural vegetation areas will be replaced by areas whose surface is difficult to evaporate and transpire. This results in a redistribution of solar radiation and triggers the contrast of surface radiance and air temperature in rural and urban areas (Aditiyanti et al., 2013).

The increase in surface temperature certainly causes discomfort in daily human activities, so humans generally need coolers such as air conditioners and fans, resulting in energy wastage and pollution. These are all links that cause the greenhouse effect, increasing the average temperature of the earth significantly (Tursilowati, 2002).

Remote sensing is a method of obtaining data or information on an area and its environment without physical touch (Riyadhi et al., 2017). Using remote sensing technology utilizing Landsat 8 OLI/TIRS Satellite Imagery, we can analyze the dynamics of surface temperature and vegetation index in the area around Mount Lokon and how these two things are related to one another.

\section{Data}

This study took a sample location of Mount Lokon, Tomohon, North Sulawesi. The tools used in this research are:

1) Laptop

2) Satellite image data of Landsat 8

3) Software QGIS

Processing of vegetation index and surface temperature in this study using Landsat 8 OLI/TIRS. Data that has been downloaded at USGS is entered in the QGIS program. Then the data is clipped raster by the extent to limit the research area by drawing on the QGIS work canvas.

The data used in this study is data taken from the USGS Earth Explorer site, namely Landsat 8 OLI/TIRS image data with path 112 and row 059 on the recording date of 8 June 2016, 20 December 2017, 2 September 2018, 4 August 2019 and 10 November 2020. The Landsat image is then cropped to focus more on Mount Lokon and its surroundings, as shown in Figure 1. 


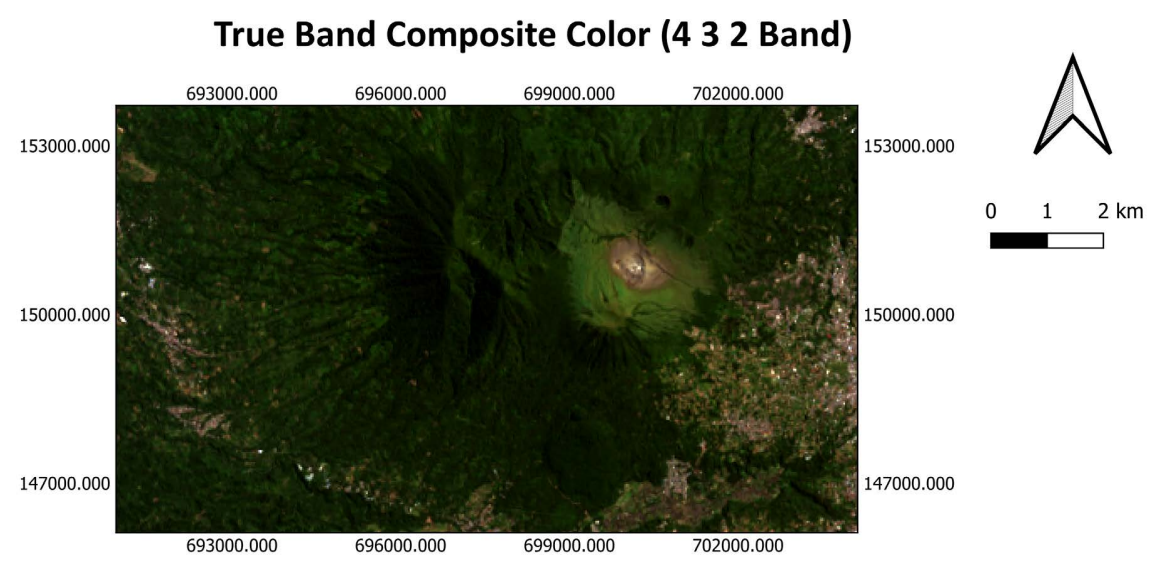

Figure 1. Image of true band composite color mount lokon.

\section{Methodology}

\subsection{Radiometric Correction}

Before processing satellite image data, radiometric correction is required using an algorithm. The primary purpose of this radiometric correction is to convert the data in the image, which is (usually) stored in the form of a digital number (DN), into radians. Radian spectral values are obtained from the metadata files that are in each Landsat satellite image data. The equation used for radiometric correction is

$$
L_{\lambda}=M_{L} \times Q_{\text {cal }}+A_{L}
$$

where $L_{\lambda}$ is the TOA spectral radiation value, $M_{L}$ as a thermal band rescaling factor, $Q_{c a l}$ the amount of heat energy and $A_{L}$ shows the value of the thermal band constant (USGS, 2019).

\subsection{Surface Temperature}

Surface temperature is one of the critical parameters for the energy balance at the surface and is also a primary climatological parameter. The surface temperature can control the longwave energy flux returning to the atmosphere and is highly dependent on the state of other surface parameters such as albedo, surface humidity, conditions, and the level of vegetation cover (Voogt, 2002). Surface temperature is how hot the earth's surface hits at a given location (from a satellite's point of view, the surface is whatever it sees as it looks through the atmosphere to the ground, be it grass on lawns, roofs of buildings, or the leaves of the canopy of forest plants). The temperature is measured at the surface level and can be considered the soil's surface temperature (Becker \& Li, 1990). In general, the highest air temperature will be in the city center and decreases gradually towards the outskirts of the city to the village and air temperature in the city where more buildings are higher than the air temperature in the surrounding areas that are more open such as suburbs or rural areas (Khusaini, 2008).

Determination of the surface temperature value is obtained by using the radiative transfer equation in Equation (1). 
The spectral radiation value is then converted into brightness temperature by referring to the metadata of each respective dataset for satellite imagery; the brightness temperature value can be used as a surface temperature reference, regarding Equation (2)

$$
T=\frac{K_{2}}{\ln \left(\frac{K_{1}}{L_{\lambda}}+1\right)}
$$

where $T$ is the temperature value in Kelvin, $K_{2} / K_{1}$ as a calibration constant obtained from the metadata, $L_{\lambda}$ is the value of the spectral radiation from equation 1 . The $T$ value is then converted to Celsius units for easy analysis.

\subsection{Vegetation Index}

The vegetation index is a quantitative measurement in measuring biomass and vegetation health, carried out by forming several spectral channels using addition, division, multiplication operations between one channel and another to obtain a value that can reflect the abundance or health of vegetation. The vegetation index's high value illustrates a high level of greenery in the observed area, such as dense and dense forest areas. Conversely, a low vegetation index value indicates that the monitored land has a low level of greenery, sparse vegetation, or is not an object of vegetation (Arhatin, 2007). Meanwhile, according to Horning (Horning, 2004), the vegetation index is a value obtained from the combination of several specific spectral bands from remote sensing images. Vegetation index waves are obtained from the energy emitted by vegetation in remote sensing images to indicate the size of life and the number of plants. Plants emit and absorb unique waves to distinguish between vegetation and objects other than vegetation so that this situation can be associated with the emission of waves from other objects. A high NDVI value indicates greener plants (closer) and vice versa. The equation for calculating NDVI (Eastman, Anyamba, \& Tucker, 2001) is:

$$
\mathrm{NDVI}=\frac{p_{1}-p_{2}}{p_{1}+p_{2}}
$$

where:

$$
\begin{aligned}
& p_{1}=\text { near-infrared band (Band 5) } \\
& \left.p_{2}=\text { red band (Band } 4\right)
\end{aligned}
$$

\section{Results and Discussion}

The average surface temperature of Lokon and its surroundings reaches $22.02^{\circ} \mathrm{C}$, then experiences dynamics of increasing and decreasing. The highest temperature change occurred from 2017 to 2018 with an average of $3.28^{\circ} \mathrm{C}$, and the highest temperature decrease occurred from 2016 to 2017 , which was $2.09^{\circ} \mathrm{C}$. The surface temperature around Mount Lokon, as shown in Figures 2-6, is centered in the east direction of Mount Lokon, Tomohon City. These results correlate 


\section{LST 2016}

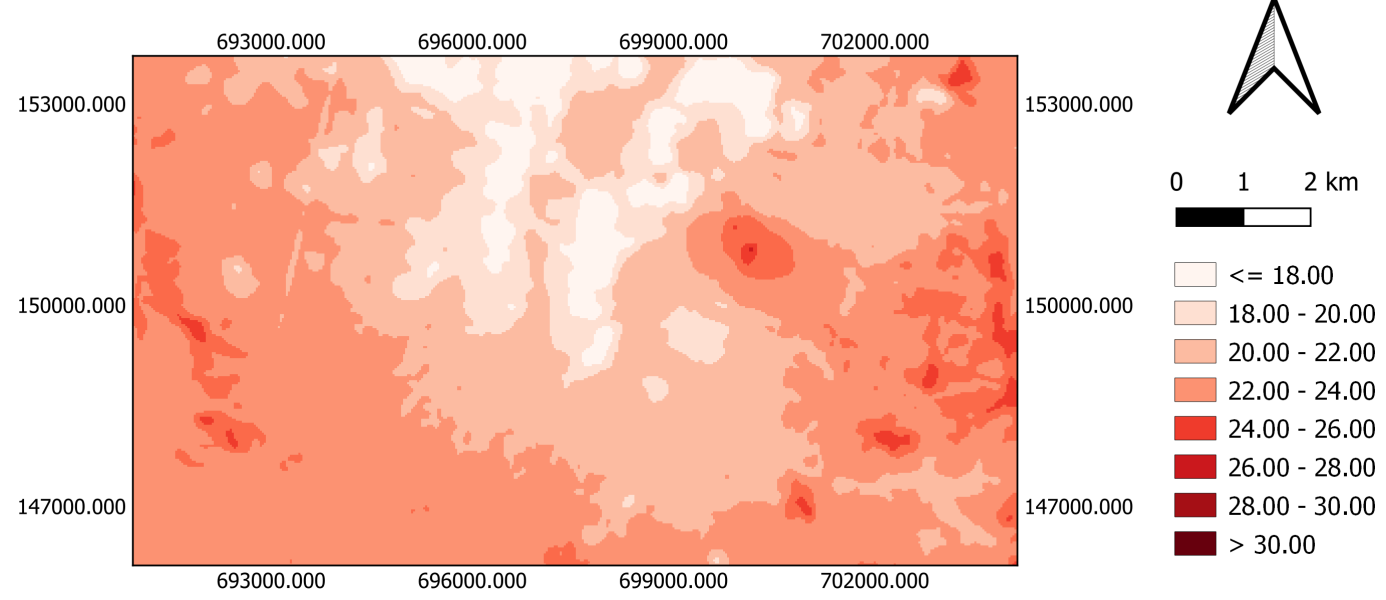

Figure 2. LST distribution in 2016.

\section{LST 2017}
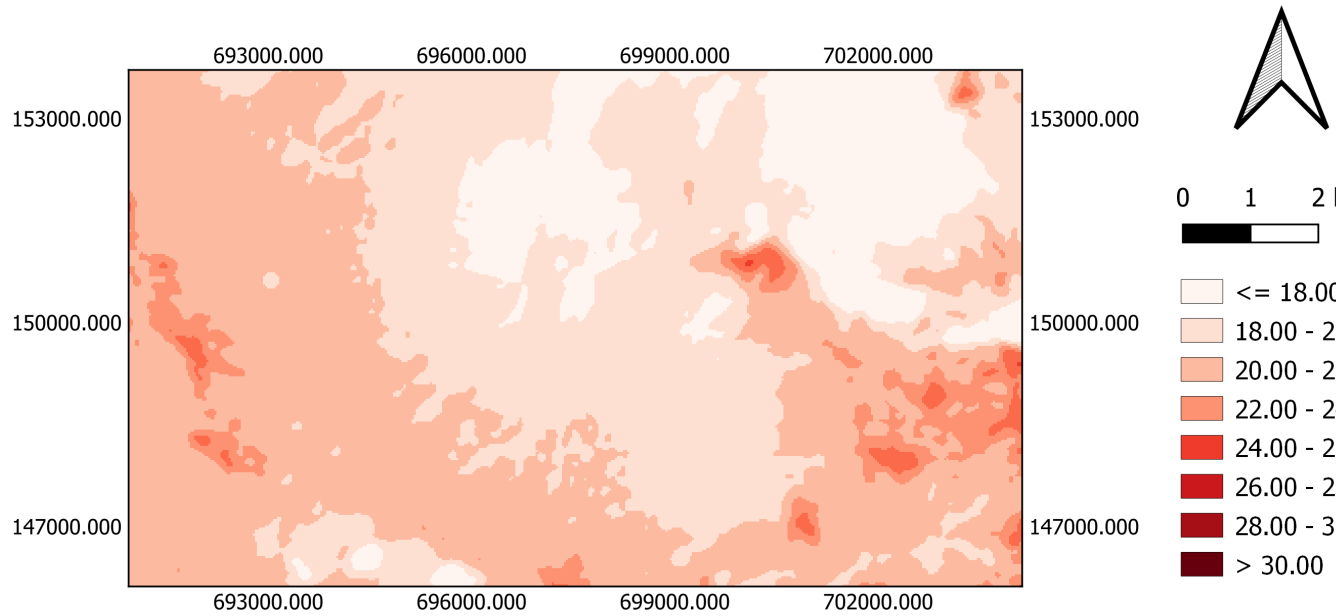

$0 \quad 1 \quad 2 \mathrm{~km}$
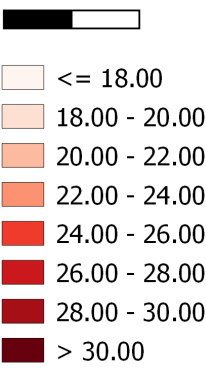

Figure 3. LST distribution in 2017.

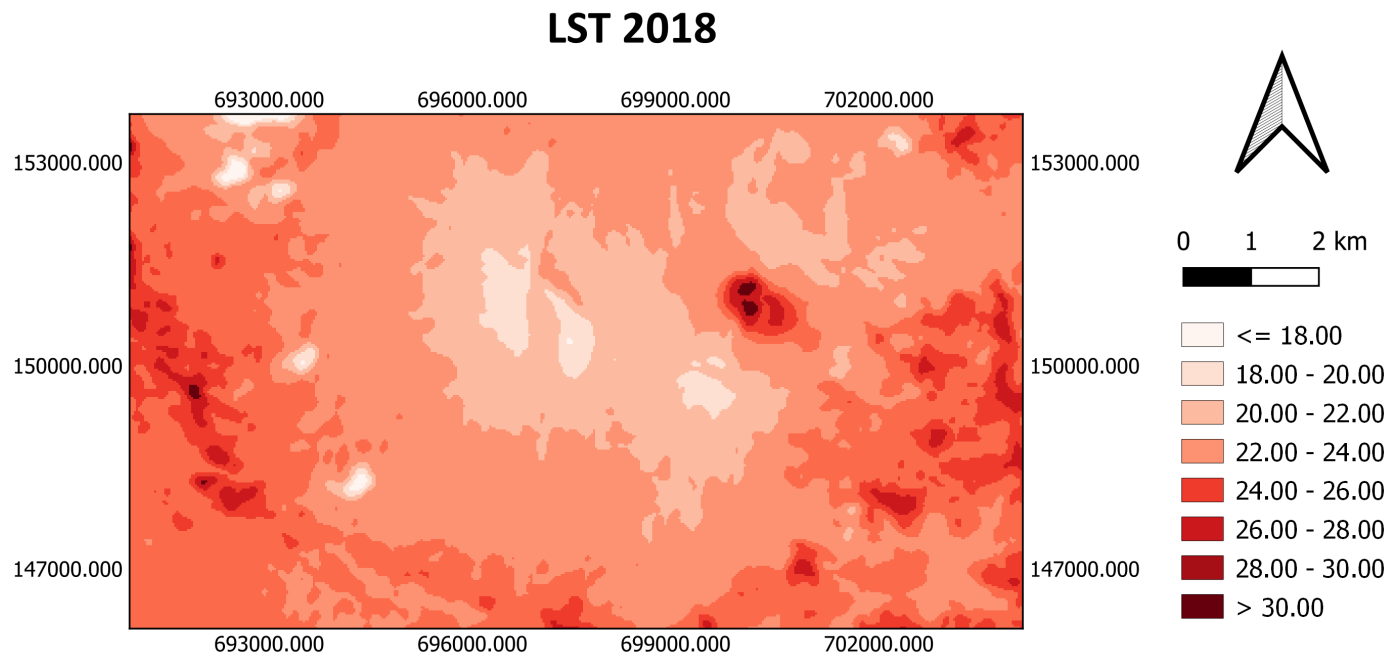

Figure 4. LST distribution in 2018. 


\section{LST 2019}

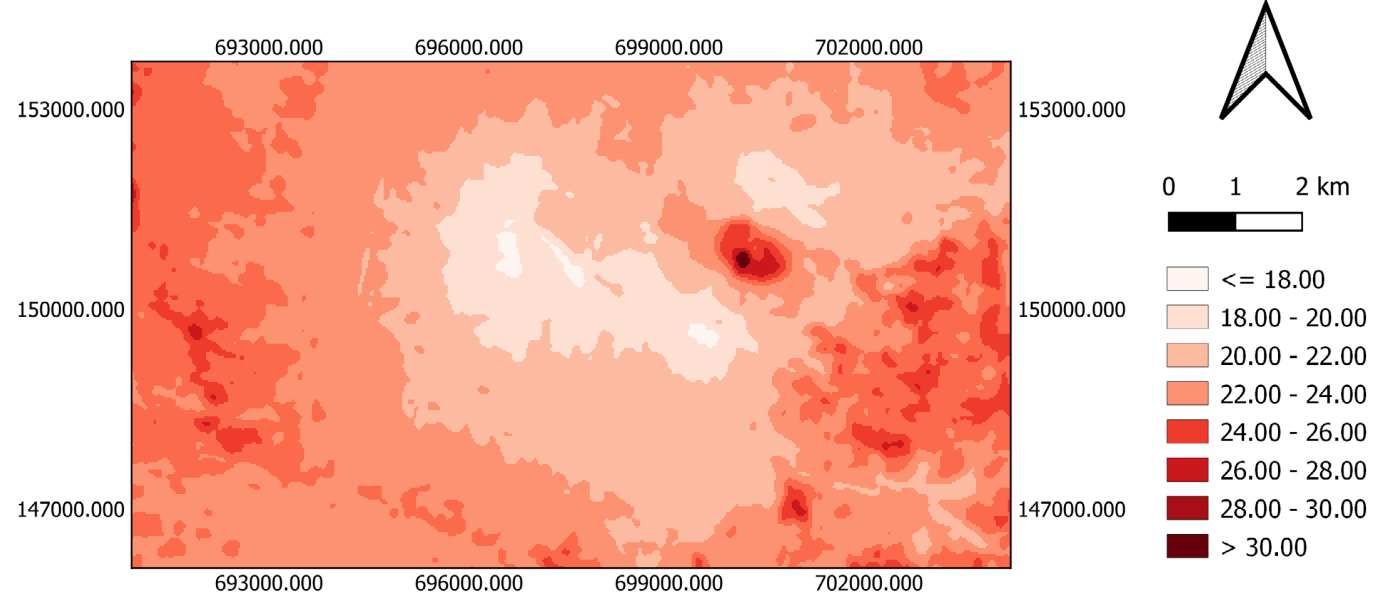

Figure 5. LST distribution in 2019.

\section{LST 2020}

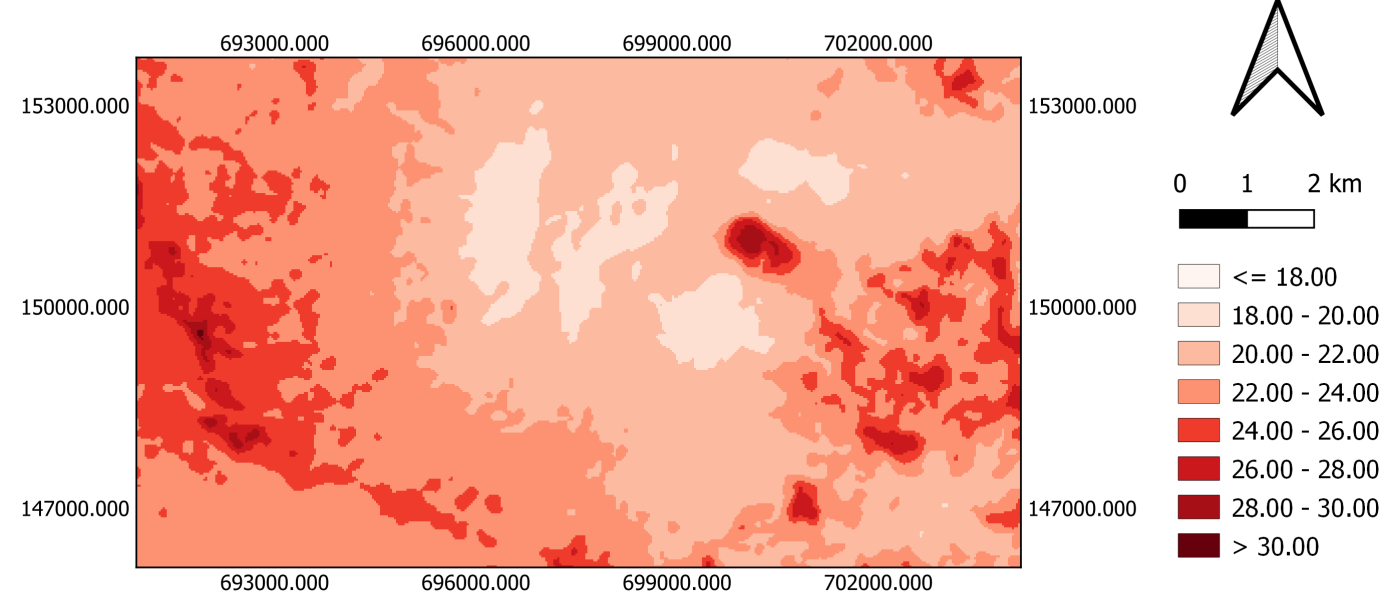

Figure 6. LST distribution in 2020.

with research results from Dede et al. (2019) high surface temperatures were found in the central business district (CBD), industrial areas, ports, congestion-prone points (traffic hours), and terminals. Surface temperatures experience dynamics with the increasing area with temperatures $>26^{\circ} \mathrm{C}$ starting in 2018, as shown in Figure 7.

Like surface temperature, the vegetation index experienced the most significant average increase dynamics from 2017 to 2018 of 0.07 . The most significant average decline in 2019-2020 was 0.02 . The extensive vegetation index in the southern and western parts of Mount Lokon in non-residential locations is shown in Figures 8-12. Locations around settlements in Tomohon City have a reasonably low vegetation index from year to year due to land conversion for settlements and settlements, which can be seen clearly in Figure 13. The statistics on the distribution of surface temperatures and the vegetation index around Mount Lokon are summarized in Table 1. 


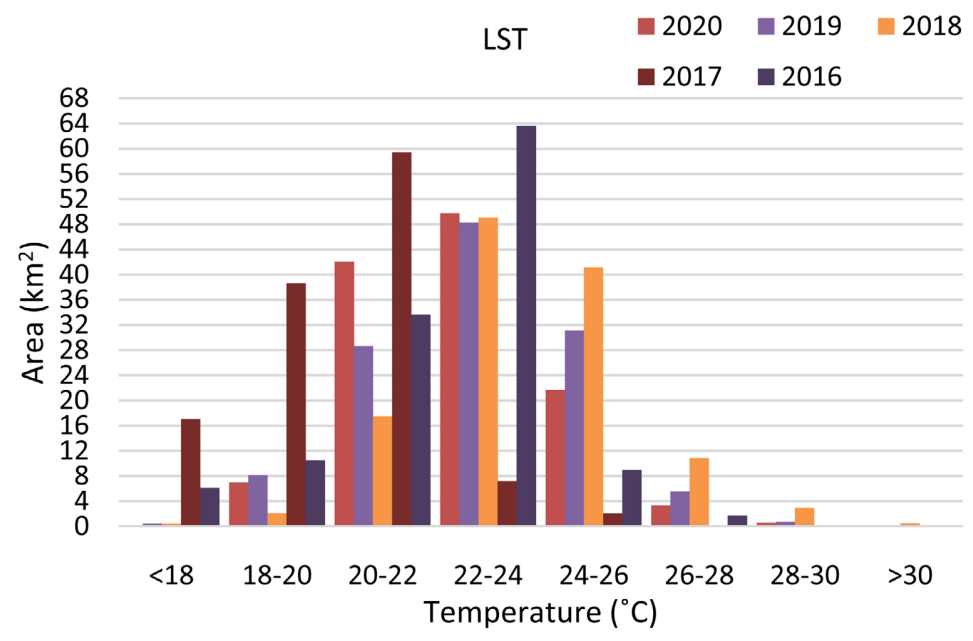

Figure 7. Surface area temperature comparison.

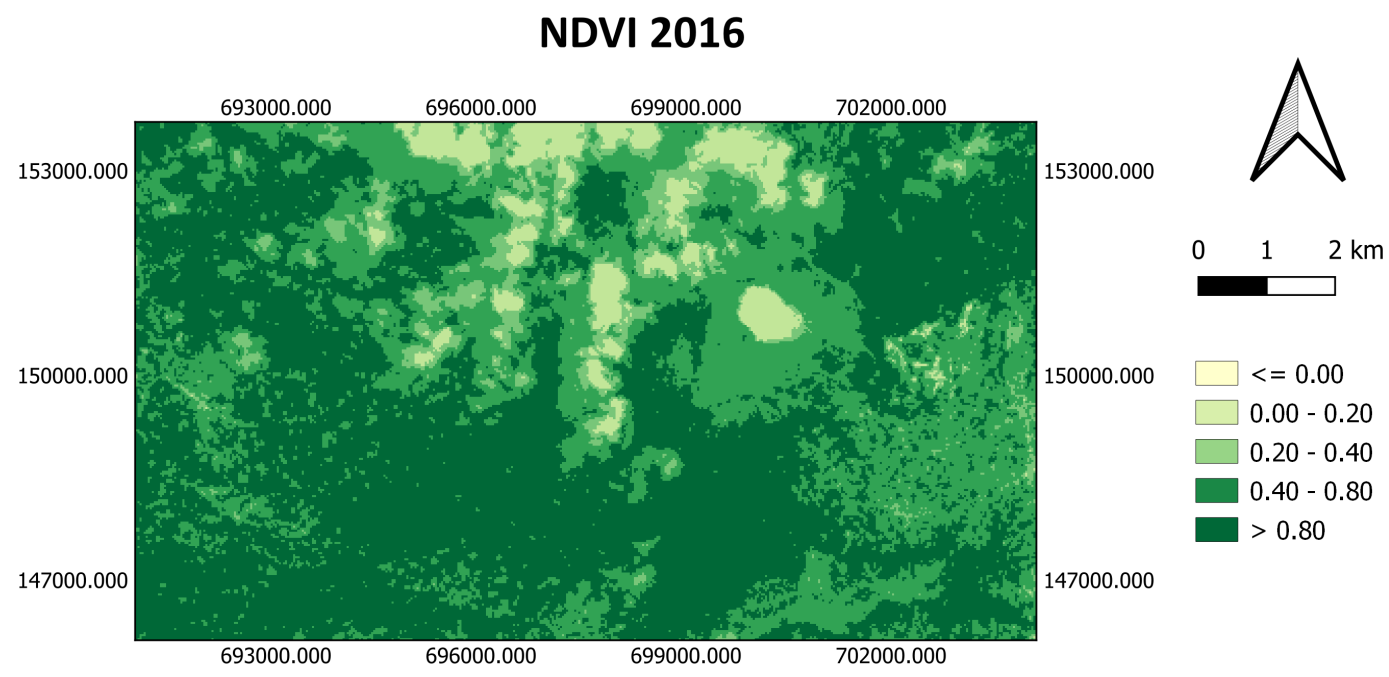

Figure 8. NDVI distribution in 2016.

NDVI 2017

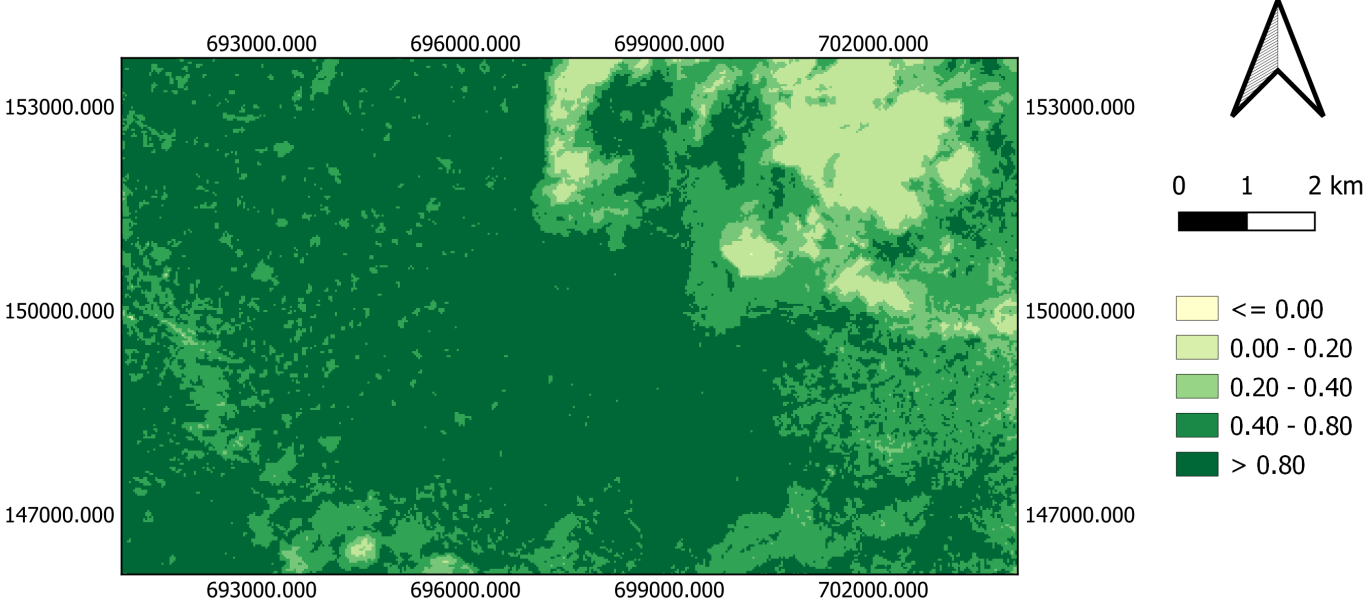

Figure 9. NDVI distribution in 2017. 


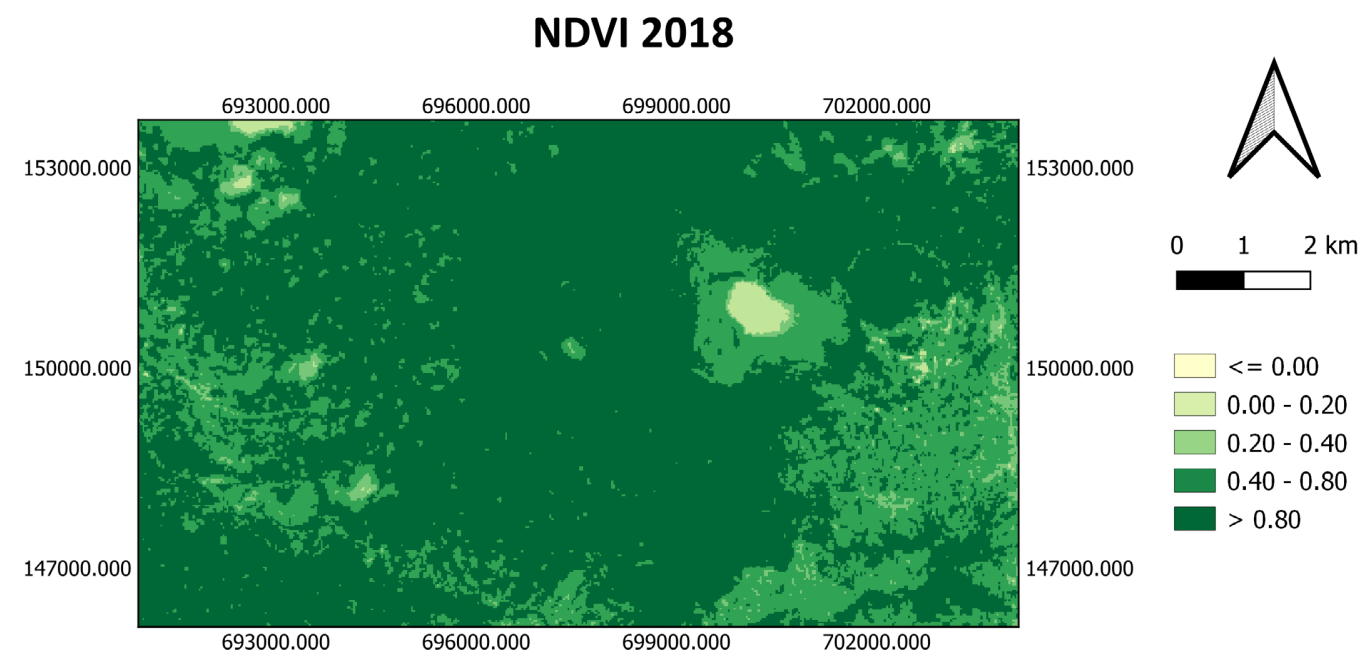

Figure 10. NDVI distribution in 2018.

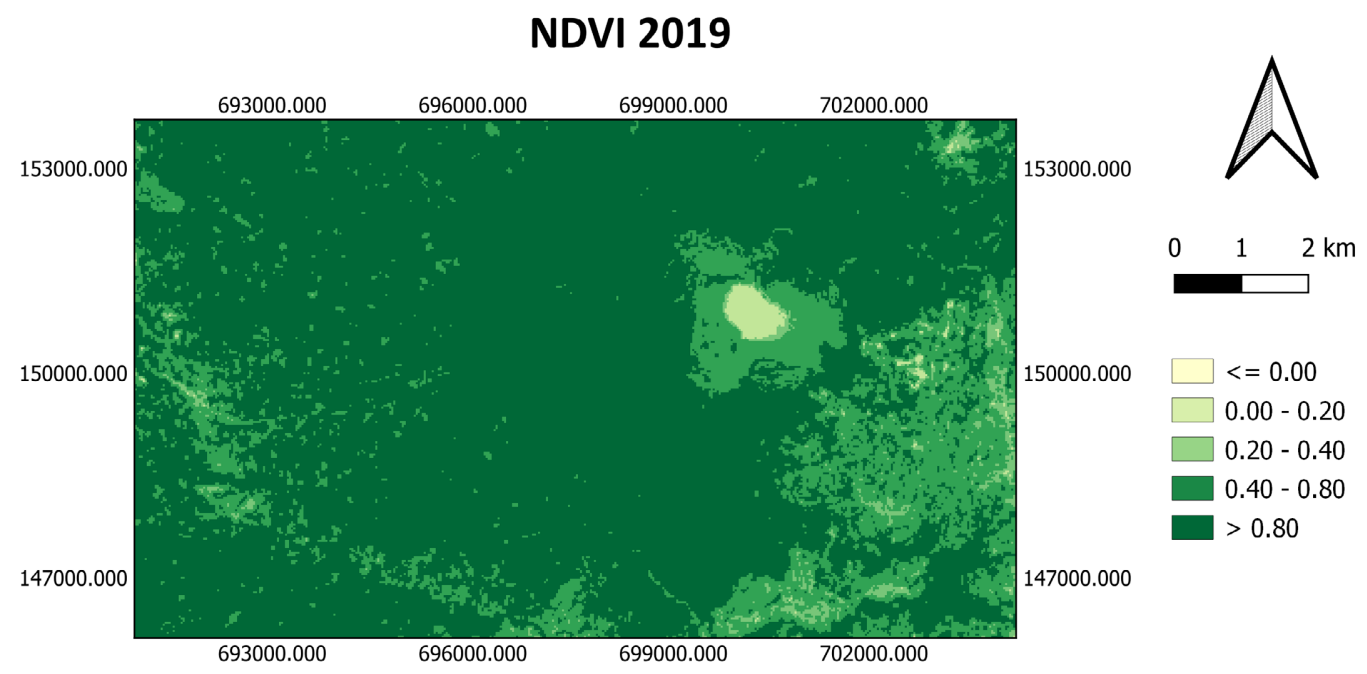

Figure 11. NDVI distribution in 2019.

\section{NDVI 2020}

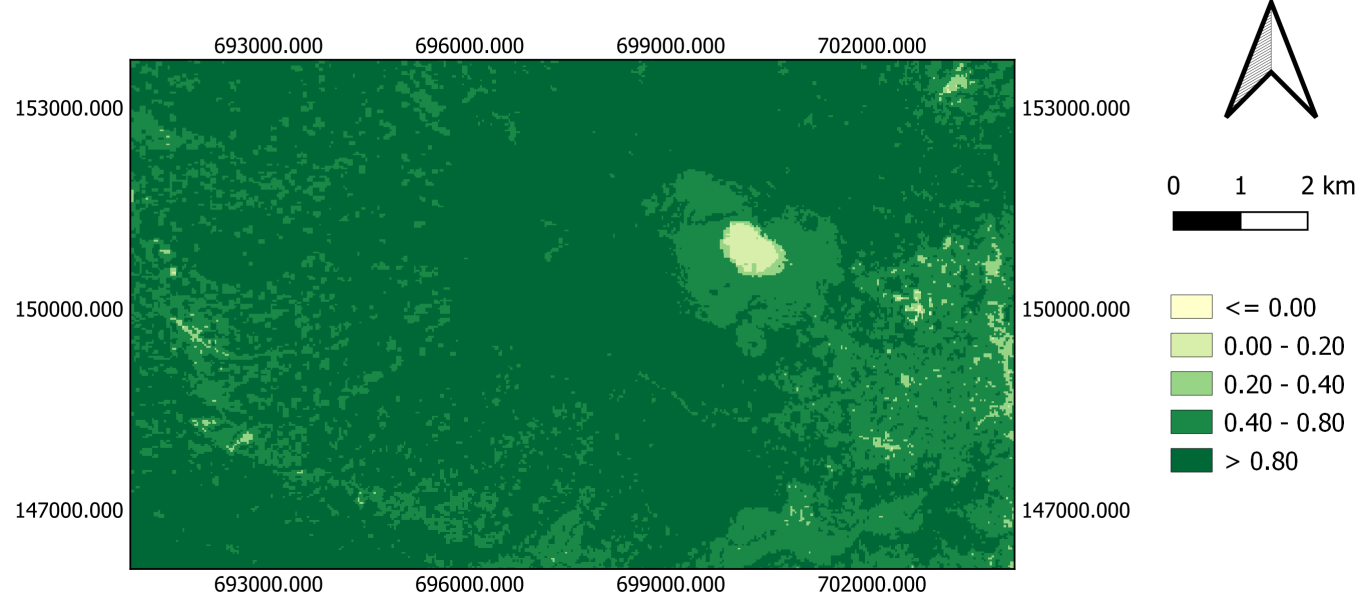

Figure 12. NDVI distribution in 2020. 


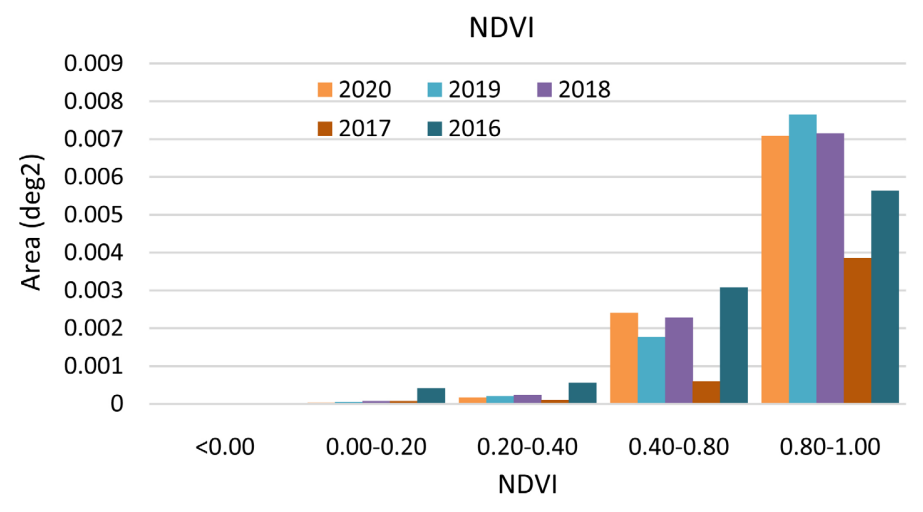

Figure 13. Vegetation index area comparison.

Table 1. Statistics of distribution of surface temperature and vegetation index around mount Lokon.

\begin{tabular}{cccccccccc}
\hline LST & Min. & Maks & Rerata & Std. Dev & NDVI & Min. & Maks & Rerata & Std. Dev \\
\hline 2016 & 15.07 & 28.5 & 22.03 & 1.91 & 2016 & 0.02 & 0.92 & 0.73 & 0.2 \\
2017 & 13.44 & 26.72 & 19.94 & 1.78 & 2017 & 0 & 0.91 & 0.73 & 0.21 \\
2018 & 14.32 & 32.12 & 23.76 & 1.98 & 2018 & 0.02 & 0.92 & 0.8 & 0.14 \\
2019 & 17.39 & 31.42 & 22.95 & 1.92 & 2019 & 0.02 & 0.95 & 0.82 & 0.13 \\
2020 & 18.15 & 31.07 & 22.58 & 1.78 & 2020 & 0.06 & 0.91 & 0.8 & 0.11 \\
\hline
\end{tabular}

Based on the temperature distribution map and the distribution of the vegetation index, several samples were taken at residential points, forests, and the crater of Mount Lokon.

The correlation between temperature and vegetation index in 2016 is obtained by the equation $y=-6.49 x+28.517$, and the value of $\mathrm{R}^{2}=0.6805$ gives an inverse relationship, as shown in Figure 14. This result was also obtained in 2017 with the equation $y=-4.0762 x+24.62$ and $\mathrm{R}^{2}=0.2064$, in 2018 with $y=$ $-0.07982 x+2.7437$ and $\mathrm{R}^{2}=0.7269$, in 2019 with $y=-0.0872 x+2.8303$ and $\mathrm{R}^{2}$ $=0.6851$, and in 2020, namely $y=-0.0759 x+2.523$ and $\mathrm{R}^{2}=0.5742$, which can be seen clearly in Figures 15-18, give each other a negative correlation value, which means they are inversely related, namely the higher the surface temperature value, the higher the vegetation index value will be low.

The surface temperature distribution around Mount Lokon increases year after year and tends to stabilize at $>31^{\circ} \mathrm{C}$ of the maximum value in 2018,2019 , and 2020. The increasing value of surface temperature around Mount Lokon is related to the decline in the vegetation index experiencing dynamics due to the interaction of environmental conditions and climatic phenomena (Dede et al, 2019).

The population of Tomohon city is increasing from year to year, and the activities of the residents have resulted in the urban heat island phenomenon. This phenomenon occurs because of the large amount of land built for settlements and the reduced vegetation in the center of Tomohon, which impacts rising surface temperatures in the area around Tomohon, including in the area around Mount Lokon. 


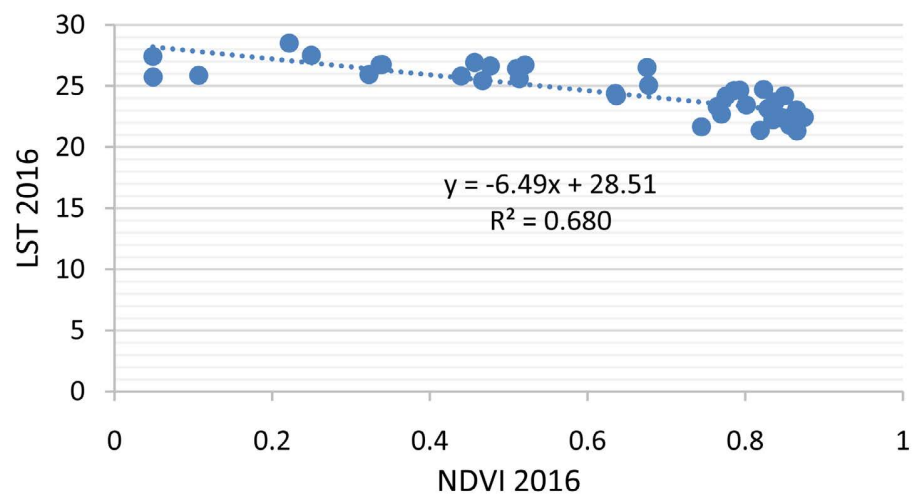

Figure 14. LST and NDVI correlation in 2016.

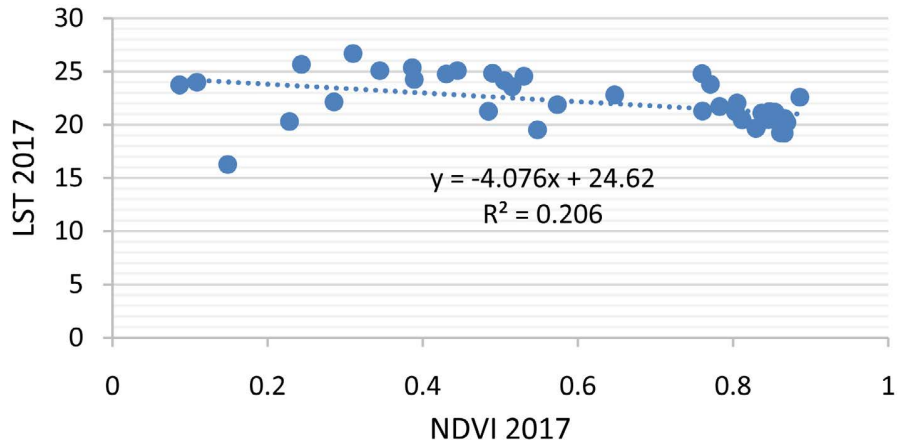

Figure 15. LST and NDVI correlation in 2017.

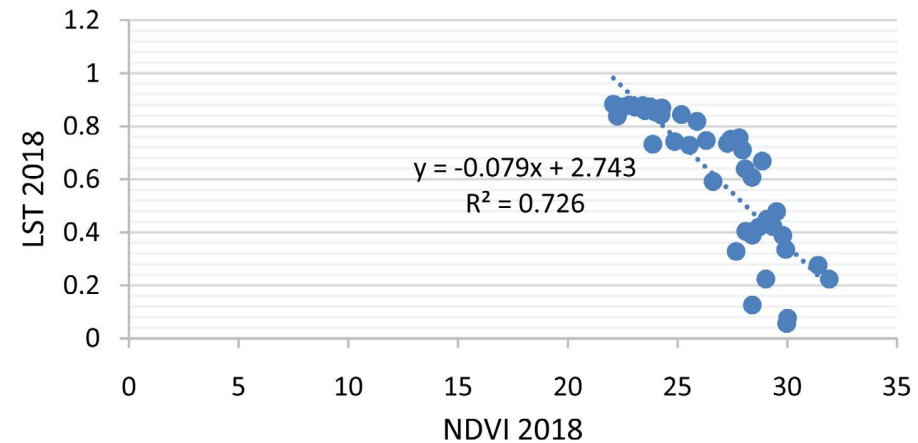

Figure 16. LST and NDVI correlation in 2018.

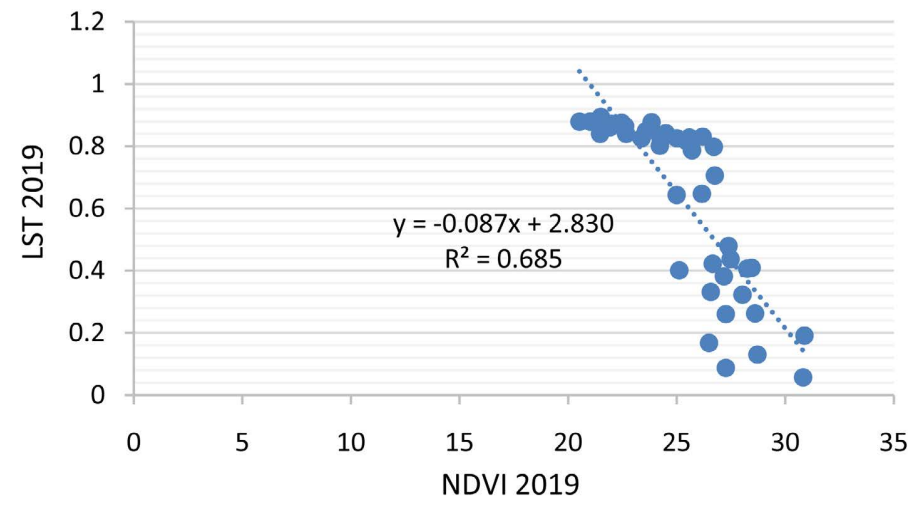

Figure 17. LST and NDVI correlation in 2019. 


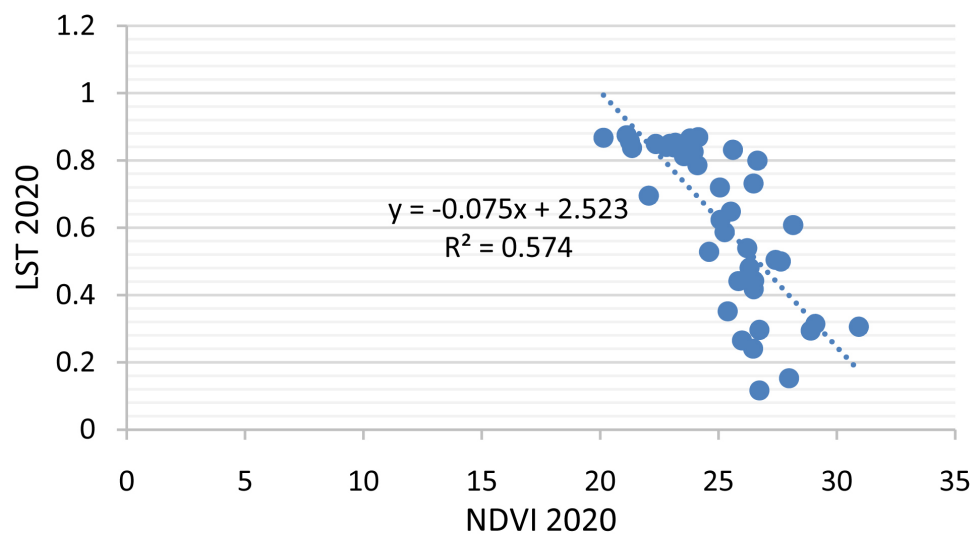

Figure 18. LST and NDVI correlation in 2020.

In 2020 there was a decrease in the average surface temperature. This result happened because of limiting people's activities due to the effects of the COVID-19 pandemic. So those industrial activities and other activities that increase the average surface temperature are reduced. This is also correlated with the vegetation index value, which tends to be stable and declining in 2020 due to several land development projects being stopped. These results follow the research conducted by Firdaus et al. (2020), where the LST comparison of the city of Jakarta before the pandemic showed a temperature of $35.96^{\circ} \mathrm{C}$, and during the pandemic, it showed a low number of $27.1^{\circ} \mathrm{C}$ to $29.88^{\circ} \mathrm{C}$.

With a strong relationship between surface temperature and vegetation index, it is necessary to prevent increased surface temperature due to human activities, such as reforestation programs in residential areas, saving electricity consumption, and controlled land management. Further research can examine the urban heat island phenomenon in settlements around Mount Lokon by paying attention to the area of land cover and population in detail. A deeper study can be carried out regarding the surface temperature and the vegetation index of the area around Mount Lokon before and during the pandemic.

\section{Conclusion}

There are dynamics of changes in temperature and vegetation index around Mount Lokon in the 2016-2020 period. The increase in average temperature has been experienced starting in 2018, areas with temperatures $>26^{\circ} \mathrm{C}$ are increasing due to the effects of industry and increased human activities causing the urban heat island phenomenon. However, in 2020, human activities and industrial activities around Mount Lokon decreased due to the effects of the COVID-19 pandemic, resulting in surface temperatures around Mount Lokon tending to be stable and decreased. This increase in average temperature is related to the decreasing vegetation index around Mount Lokon, so efforts are needed to overcome the increase in surface temperature further related to the reforestation process so that environmental conditions for living things around Mount Lokon feel comfortable. 


\section{Conflicts of Interest}

The authors declare no conflicts of interest regarding the publication of this paper.

\section{References}

Aditiyanti, A., Sabri, L. M., \& Sasmito, B. (2013). Analisis Pengaruh Perubahan NDVI dan Tutupan Lahan Terhadap Suhu Permukaan Di Kota Semarang. Jurnal Geodesi Undip, 2, 10-19.

Arhatin, R. E. (2007). Pengkajian Algoritma Indeks Vegetasi dan Metode Klasifikasi Mangrove darti Data Satelit Landsat-5 dan Landsat 7 ETM+ (Studi Kasus di Kabupaten Berau, Kaltim). Bogor: IPB.

Becker, F., \& Li, Z. L. (1990). Towards a Local Split Windows Method over Land Surfaces. International Journal of Remote Sensing, 11, 369-393. https://doi.org/10.1080/01431169008955028

Dede, M., Pramulatsih, G. P., Widiawaty, M. A., Ramadhan, Y. R., \& Ati, A. (2019). Dinamika Suhu Permukaan dan Kerapatan Vegetasi di Kota Cirebon. Jurnal Meteorologi Klimatologi dan Geofisika, 6, 23-30.

Eastman, J. R., Anyamba, A., \& Tucker, C. J. (2001). NDVI Anomaly Patterns over Africa during the 1997/98 ENSO Warm Event. International Journal of Remote Sensing, 22, 1847-1859. https://doi.org/10.1080/01431160010029156

Firdaus, N. S., Lestari, D. P., \& Baru, A. M. (2020). Perbandingan Suhu Permukaan Tanah Sebelum dan Selama Pandemi Covid-19 Menggunakan Citra Landsat 8 di Jakarta. Prosiding Nasional dan Call for Paper BEM Geografi UMS ke-1 (pp. 35-42). Surakarta: Publikasi UMS.

Horning, N. (2004). Global Land Vegetation; an Electronic Textbook. NASA Goddard Space Flight Center Earth Sciences Directorate Scientific and Educational Endeavors (SEE). Maryland-USA.

Khusaini, N. I. (2008). Undergraduate Thesis: Pengaruh Perubahan Penutupan Lahan Terhadap Distribusi Suhu Permukaan di Kota Bogor Dengan Menggunakan Citra Satelit Landsat dan Sistem Informasi Geografis. Bogor, Institut Pertanian Bogor.

Pusat Vulkanologi dan Mitigasi Bencana Geologi (2014). G. Lokon. Retrieved from Kementerian Energi dan Sumber Daya Mineral:

https://vsi.esdm.go.id/index.php/kegiatan-pvmbg/download-center/doc_download/393 -g-lokon

Riyadhi, A. F., Wardhana, F. S., \& GNR, P. J. (2017). Analisa Distribusi Temperatur Permukaan Tanah Tompaso, Minahasam Sulawesi Utara Menggunakan Citra Satelit Landsat-8. Seminar Nasional Kebumian Ke-10 (pp. 1827-1835). Yogyakarta: Fakultas Teknik UGM.

Tursilowati, L. (2002). Urban Heat Islan dan Kontribusinya Pada Perubahan Iklim dan Hubungannya Dengan Perubahan Lahan. Prosiding Seminar Nasional Pemanasan Global dan Perubahan Global-Fakta, Mitigasi, dan Adaptasi (pp. 89-96). Pusat Pemanfaatan Sains Atmosfer dan Iklim LAPAN.

USGS (2019). Landsat 8 (L8) Data Users Handbook Version 5.0. Sioux Falls: Department of the Interior U.S. Geological Survey. Retrieved from USGS.

Voogt, J. A. (2002). Urban Heat Island. In: I. Douglas, (Ed) Volume 3, Causes and Consequences of Global Environment Change. In: T. Munn, (Ed). Encyclopedia of Global Environment Change. Chichester: John Wiley \& Son, Ltd. 